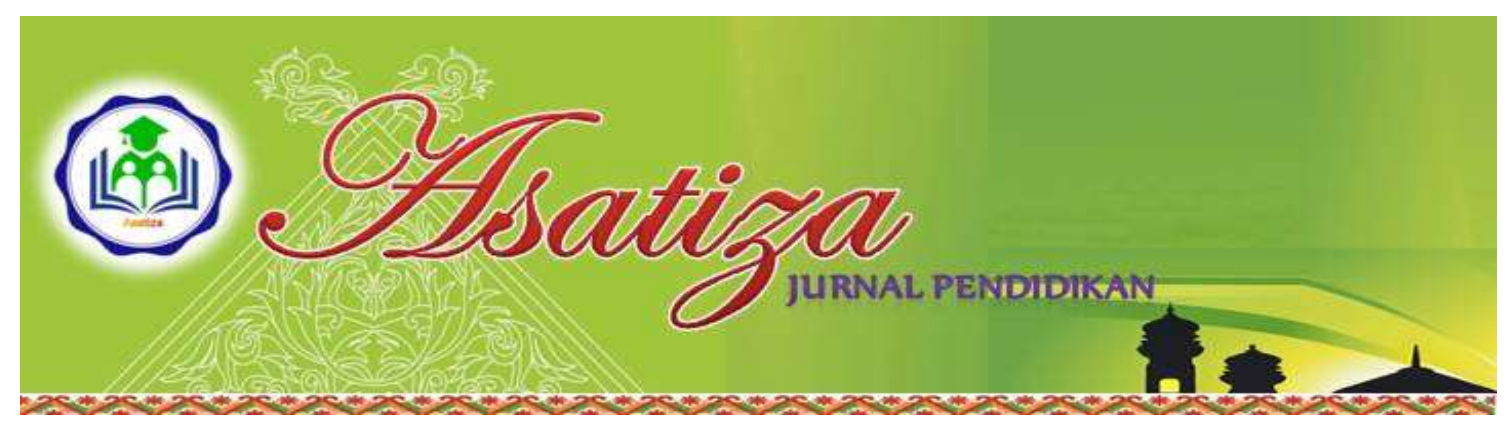

\title{
PENGARUH METODE SCRAMBLE TERHADAP HASIL BELAJAR SISWA PADA MATA PELAJARAN PENDIDIKAN AGAMA ISLAM SEKOLAH DASAR NEGERI 007 TEMBILAHAN HILIR KECAMATAN TEMBILAHAN KABUPATEN INDRAGIRI HILIR Yenni Oktavia ${ }^{1}$
}

\author{
${ }^{1}$ Mahasiswi Prodi PAI STAI Auliurrasyidin Tembilahan, Indonesia
}

\begin{abstract}
Abstrak
Tujuan penelitian ini adalah untuk mengetahui pengaruh antara penggunaan metode scramble dengan hasil belajar siswa di Sekolah Dasar Negeri 007 Tembilan Hilir. Manfaat penelitian ini adalah Sebagai bahan informasi untuk meningkatkan mutu pembelajaran dan metode mengajar guru dengan hasil belajar siswa di Sekolah Dasar Negeri 007 Tembilan Hilir.

Subjek dalam penelitian ini adalah guru mata pelajaran dan Siswa kelas IV, V, dan VI di Sekolah Dasar Negeri 007 Tembilan Hilir. Sedangkan yang menjadi objek dalam penelitian ini adalah pengunaan metode scramble. Teknik pengumpulan data melalui observasi, dan dokumentasi, teknik analisa data dengan rumus uji t.

Hasil penelitian pada taraf signifikansi $5 \% \mathrm{t},-\mathrm{t}_{\text {tabel }} \leq \mathrm{t}_{\text {hitung, }}$ atau $-1,994 \leq-60,64$. Dengan kesimpulan terdapat pengaruh penggunaan metode scramble terhadap hasil belajar siswa pada kelas IV, V, VI di Sekolah Dasar Negeri 007 Tembilahan Hilir.
\end{abstract}

Kata Kunci: Metode scramble, Hasil Belajar

\section{A. PENDAHULUAN}

\section{Latar belakang}

Menurut Zuhairini tujuan

Pendidikan agama Islam di lembagalembaga pendidikan formal di Indonesia ini dapat dibagi menjadi dua macam, yaitu tujuan umum dan khusus. ${ }^{1}$

Pertama, tujuan umum pendidikan agama ialah membimbing anak agar mereka menjadi orang Muslim sejati, beriman, teguh, beramal saleh, dan berakhlak mulia serta berguna bagi

${ }^{1}$ Ahmad Susanto, Teori Belajar dan Pembelajaran di Sekolah Dasar, (Jakarta: Kencana Prenadamedia Group, 2013), Cet ke-1, h. $280-281$ masyarakat, agama, dan negara. Tujuan pendidikan agama tersebut merupakan tujuan yang hendak dicapai oleh setiap orang yang melaksanakan pendidikan agama. Karena dalam mendidik agama yang perlu ditanamkan terlebih dahulu ialam keimanan yang teguh, sebab dengan adanya keimanan yang teguh, maka akan menghasilkan ketaatan menjalankan kewajiban agama.

Kedua, tujuan khusus pendidikan agama ialah tujuan pendidikan agama pada setiap tahap atau tingkat yang dilalui seperti tujuan pendidikan agama disekolah dasar berbeda dengan tujuan pendidikan agama untuk sekolah 
menengah dan berbeda untuk perguruan tinggi. Adapun tujuan pendidikan agama Islam untuk tingkat sekolah dasar, yaitu : (1) Penanaman rasa agama kepada peserta didik. (2)Menanam perasaan cinta kepada Allah dan Rasul-Nya. (3) Memperkenalkan ajaran Islam yang bersifat global, seperti rukun Islam, dan Rukun Iman. (4) membiasakan anakanak berakhlak mulia, dan melatih anakanak untuk mempraktikkan ibadah yang bersifatpraktis, seperti shalat, dan puasa.

(5) Membiasakan contoh teladan yang baik.

Berbagai upaya untuk meningkatkan kualitas pendidikan di Sekolah Dasar (SD), telah dilakukan pemerintah dengan tujuan untuk menyiapkan masa depan sumberdaya manusia yang berkualitas. Guru sebagai ujung tombak dalam rangka peningkatan mutu pendidikan perlu menyesuaikan diri seiring dengan tuntutan masyarakat dan paradigma pendidikan masa kini. Sebagai praktisi di kelas guru sangat dituntut untuk menjalankan perannya antara lain sebagai motivator, edukator, fasilitator, dan administrator.

Implementasi proses pembelajaran di kelas perlu diterapkan metode pembelajaran yang membuat siswa aktif,inovatif, lingkungan, kreatif, efektif, dan menarik dapat tercapai. Keberhasilan Pembelajaran Pendidikan Agama Islam juga tergantung pada strategi dan metode pembelajaran yang tepat, dan hasil belajar siswa tidak hanya tergantung pada sarana dan prasarana pendidikan, kurikulum maupun metode, akan tetapi guru mempunyai posisi yang strategis dalam meningkatkan hasil belajar siswa dalam penggunaan metode yang tepat, dan mampu memotivasi siswa dalam pembelajaran Pendidikan Agama Islam. Ragam metode dapat memberi keleluasaan kepada guru untuk menggunakan metode-metode mengajar. Hal ini penting, karena suatu metode mengajar dapat digunakan untuk merangsang, terutama untuk menarik minat terhadap pelajaran yang disampaikan.

Dalam proses interaksi edukatif kedudukan metode mengajar sangat penting, karena pengertian metode tidaklah hanya sekedar suatu cara, akan tetapi merupakan teknik di dalam proses penyampaian materi pengajaran. Di dalam sebuah istilah metode mengajar terkandung dua pengertian yang bila disatukan menjadi satu pengertian kegiatan yang menunjang pencapaian tujuan-tujuan pengajaran. Bila dirinci antara metode dan mengajar, terdapat satu hubungan yang kuat yang tidak dapat dipisah. Metode mengajar berfungsi pula sebagai alat yang tetap untuk menambah partisipasi peserta didik dan menanamkan kepemimpinan dengan usaha menciptakan situasi mengajar dan belajar yang tepat dan berguna. $^{2}$

Metode scramble berbentuk permainan acak kata, kalimat, atau paragraf. Pembelajaran metode scramble adalah sebuah metode yang menggunakan penekanan latihan soal berupa permainan yang dikerjakan secara berkelompok. Dalam metode pembelajaran ini perlu adanya kerjasama antar anggota kelompok untuk saling

${ }^{2}$ Zainal Arsil, Micro Teaching, (Jakarta: PT. Raja Grafindo, 2012), Cet ke-4 h.5 
membantu teman sekelompok untuk dapat berfikir kritis sehingga dapat lebih mudah mencari penyelesaian soal.

Metode permainan ini diharapkan dapat memacu hasil belajar siswa dalam pelajaran Pendidikan Agama Islam.

Menurut Suyatno model pembelajaran kooperatif tipe scramble adalah, salah satu tipe pembelajaran kooperatif yang disajikan dalam bentuk kartu. Tahapannya adalah sebagai berikut: ${ }^{3}$

a. Guru membuat soal sesuai dengan materi yang akan disajikan kepada siswa.

b. Guru membuat pilihan jawaban yang susunannya diacak sesuai jawaban soal-soal pada kartu soal.

c. Guru menyajikan materi ajar kepada siswa.

d. Guru membagikan kartu soal dan membagikan kartu jawaban sebagai pilihan jawaban soal-soal pada kartu soal.

e. Siswa berkelompok dan saling membantu mengerjakan soal-soal yang ada pada kartu soal.

f. Siswa mencari jawaban yang cocok untuk setiap soal yang mereka kerjakan dan memasangkannya pada kartu soal.

Pembelajaran kooperatif merupakan pembelajaran yang mengutamakan adanya kerjasama antar siswa dalam kelompok untuk mencapai tujuan pembelajaran. Para siswa dibagi dalam kelompok-kelompok kecil dan diarahkan untuk mempelajari materi yang telah di tentukan. Model pembelajaran

${ }^{3}$ http://yusiriza.wordpress.com/2011/07/20/ model-pembelajaran-kooperatif-tipe-scramble/, diakses tanggal 12 Februari 2015. kooperatif merupakan suatu model pembelajaran yang membantu siswa dalam mengembangkan pemahaman dan sikapnya sesuai dengan kehidupan masyarakat, sehingga bekerja sama-sama di antara sesama anggota kelompok dan meningkatkan motivasi, produktivitas, dan perolehan belajar. ${ }^{4}$

Pembelajaran kooperatif merupakan pembelajaran yang dapat memotivasi belajar siswa dimana kekurangan yang mungkin terjadi dapat diminimalisir. Pembelajaran kooperatif dengan metode scramble mempunyai kelebihan. Kelebihannya tipe ini antara lain: (a) memudahkan siswa untuk menemukan jawaban; (b) mendorong siswa untuk mengerjakan soal tersebut karena jawaban sudah tersedia; (c) semua siswa terlibat; (d) kegiatan tersebut dapat mendorong pemahaman siswa terhadap materi pelajaran. ${ }^{5}$

\section{Pengertian Metode Scramble}

Proses belajar mengajar merupakan interaksi antara guru dengan peserta didik dalam suatu pengajaran untuk mewujudkan tujuan yang di tetapkan. Berbagai pendekatan yang dipergunakan dalam pembelajaran Pendidikan Agama Islam yang bersifat prosedural. "Segala sesuatu ada jalannya, dan jalan yang ke surga ialah ilmu (Ilmu Agama)" (HR. Ad Dailami). ${ }^{1}$

Secara umum metode pembelajaran di definisikan sebagai cara yang

${ }^{4}$ Etin, Solihatin, COOPERATIVE LEARNING Analisis Model Pembelajaran IPS, (Jakarta: Bumi Aksara, 2008), cet ke-3 h. 5

${ }^{5}$ M. Hanafi, Pembelajaran SKI di MI, (Jakarta: Kementerian Agama RI, 2010), h. 4647.

${ }^{1}$ Moh. Rafa'i, 300 hadits Bekal Da'wah dan Pembinaan Probadi Muslim (Semarang: Wicaksana, 1980), h. 45-46 
digunakan guru dalam menjalankan fungsinya dan merupakan alat untuk mencapai tujuan pembelajaran. Selain itu metode juga dapat di artikan sebagai suatu cara yang dipergunakan untuk mencapai tujuan yang telah ditetapkan. Dalam kegiatan belajar mengajar diperlukan oleh guru dan penggunaannya bervariasi sesuai dengan tujuan yang ingin dicapai setelah pembelajaran berakhir.

Seorang guru tidak akan dapat melaksanakan tugasnya bila dia tidak menguasai satupun metode mengajar. Banyak metode yang dapat digunakan dalam pembelajaran Agama Islam, yang hampir tidak berbeda jauh dengan metode-metode yang dapat digunakan dalam pembelajaran mata pelajaran lainnya. Banyak atau beragamnya metode dalam pembelajaran agama ini karena akan sangat tergantung pada kekhususan-kekhususan yang ada pada masing-masing bahan/materi pelajaran, baik sifat maupun tujuan, maka diperlukan metode-metode yang berlainan. Selain itu, perbedaan latar belakang individual anak, baik latar belakang kehidupan, tingkat usianya maupun tingkat kemampuan berpikirnya, perbedaan situasi dan kondisi dimana pendidikan berlangsung, dan perbedaan pribadi dan kemampuan dari para pendidik masing-masing juga dapat menjadi faktor penyebab banyaknya metode yang digunakan. ${ }^{2}$

Dalam kegiatan belajar mengajar, guru tidak harus terpaku dengan

${ }^{2}$ Ahmad Susanto, Teori Belajar dan Pembelajaran di Sekolah Dasar, (Jakarta: Kencana Prenadamedia Group, 2013), Cet ke-1, h. 281 menggunakan satu metode, tetapi guru sebaiknya menggunakan metode bervariasi agar jalannya pengajaran tidak membosankan, tetapi menarik perhatian anak didik. Namun penggunaan metode yang bervariasi tidak akan menguntungkan kegiatan pembelajaran bila penggunaannya tidak tepat dan sesuai dengan situasi yang mendukung dan dengan kondisi psikologi anak didik. Oleh karena itu penulis, menjelaskan salah satu metode yang dapat di gunakan dalam pembelajaran Pendidikan Agama Islam, yaitu Metode Scramble.

Metode Scramble merupakan suatu metode mengajar dengan membagikan lembar soal dan lembar jawaban yang disertai dengan alternatif jawaban yang tersedia. Siswa diharapkan mampu mencari jawaban dan cara penyelesaian dari soal yang ada. Menurut Suyatno, Scramble merupakan salah satu tipe pembelajaran kooperatif yang disajikan dalam bentuk kartu.

Metode Scramble merupakan metode menyajikan materi ajar melalui pengajuan pertanyaan atau pernyataan yang kurang lengkap sehingga pada peserta didik diserukan untuk melengkapi pernyataan maupun menjawab pertanyaan yang telah tersedia. ${ }^{3}$

Metode Scramble terdiri dari beberapa macam bentuk yaitu :

a. Scramble kata, yakni sebuah permainan menyusun kata-kata dan huruf-huruf yang telah dikacaukan letaknya sehingga membentuk suatu kata tertentu yang bermakna misalnya

${ }^{3}$ Istarani, 58 Model Pembelajaran Inovatif, (Medan: Perpustakaan Nasional Republik Indonesia, 2004), cet. 3, h. 185 
$:$ Nahdima $=$ Madinah kahkme $=$ mekkah

b. Scramble kalimat : yakni sebuah permainan menyusun kalimat dari kata-kata acak. Bentuk kalimat hendaknya logis, bermakna, tepat, dan benar.

c. Scramble wacana: yakni sebuah permainan menyusun wacana logis berdasarkan kalimat-kalimat acak. Hasil susunan wacana hendaknya logis, bermakna.

Melalui pembelajaran kooperatif metode scramble, siswa dapat dilatih berkreasi menyusun kata, kalimat, atau wacana yang acak susunannya dengan susunan yang bermakna dan mungkin lebih baik dari susunan aslinya.

\section{Langkah-Langkah Penggunaan Metode Scramble}

Metode ini membutuhkan media dengan pertanyaan dan jawaban yang ditulis pada sebuah kertas. Pertanyaan yang dibuat disesuaikan dengan bahan ajar yang harus dikuasai peserta didik. Jawaban atas pertanyaan diberikan pada lembar yang sama dengan mengacak hurufnya. ${ }^{4}$

Adapun langkah-langkah penggunaan metode ini ialah :

a. Guru dapat menyajikan materi sesuai dengan kompetensi yang ingin dicapai.

b. Guru mempersiapkan pertanyaan yang bersifat melengkapi dari suatu pernyataan.

c. Guru membuat pertanyaan yang sesuai dengan materi.

${ }^{4}$ Ridwan Abdullah Sani, Inovasi Pembelajaran, (Jakarta: Bumi Aksara, 2013), h.209 d. Guru memberikan contoh cara mengerjakan pertanyaan-pertanya an tersebut.

e. Kemudian membagikan lembar kerja yang akan di kerjakan peserta didik.

f. Guru mengoreksi secara bersamasama dengan siswa hasil lembar kerja.

g. Pengambilan kesimpulan.

h. Penutup. ${ }^{5}$

Contoh 1 : Susunlah huruf-huruf pada kolom sehingga merupakan kata kunci (jawaban) dari pertanyaan kolom A. ${ }^{6}$

\section{Penerapan Metode Scramble pada} mata pelajaran Pendidikan Agama Islam (PAI)

Pendidikan Agama Islam adalah upaya sadar dan terencana dalam menyiapkan peserta didik untuk mengenal, memahami, menghayati, hingga mengimani, bertakwa, dan berakhlak mulia dalam mengamalkan ajaran agama Islam dari sumber utamanya kitab suci Al-Qur'an dan Hadits, melalui kegiatan bimbingan, pengajaran, latihan, serta penggunaan pengalaman. $^{7}$

Ahmad Tafsir mendefenisikan Pendidikan Islam sebagai bimbingan yang diberikan oleh seseorang agar ia berkembang secara maksimal sesuai dengan ajaran Islam. $^{8}$ Dengan penggunaan metode Scramble pendidik

${ }^{5}$ loc.cit. Istarani, h. 185

${ }^{6}$ Hamzah, Dkk, Belajar Dengan Pendekatan PAILKEM: Pembelajaran Aktif, Inovatif, Lingkungan, Kreatif, Efektif, Menarik, (Jakarta: PT. Bumi Aksara, 2013), h.93

${ }^{7}$ Abdul Majid, Belajar dan Pembelajaran Pendidikan Agama Islam (Bandung: PT. Remaja Rosdakarya, 2012) h, 11

${ }^{8}$ Ahmad Tafsir, Ilmu Pendidikan Dalam Persfektif Islam, (Bandung: PT. Remaja Rosdakarya, 2005), h.45 
dapat meningkatkan daya pemikiran siswa. Metode ini bisa mendorong siswa untuk berfikir secara aktif dengan materi (kata acak) yang ada.

Siswa dianjurkan untuk menjawab pertanyaan yang kata-katanya diacak. Permainan ini sangat baik untuk mengambangkan daya pikir tinggi siswa. Dengan cara seperti ini pembelajaran yang berupa sejarah yang tua di dalam Pendidikan Agama Islam terasa lebih segar dan dekat dengan peserta didik. ${ }^{9}$

Di bawah ini dicontohkan penggunaan metode Scramble pada mata pelajaran Pendidikan Agama Islam.

a. Guru membuat pertanyaan sesuai dengan kompetensi yang ingin dicapai.

b. Membuat jawaban yang hurufnya diacak.

Adapun kelebihan penggunaan metode scramble antara lain :

a. Siswa akan sangat terbantu dalam mencari jawaban.

b. Mendorong siswa untuk belajar mengerjakan soal tersebut.

c. Semua siswa dapat terlibat aktif.

d. Kegiatan pembelajaran ini mendorong pemahaman siswa terhadap materi pelajaran dengan bantuan teman-temannya sesama siswa.

e. Adanya pembelajaran sikap disiplin.

Sedangkan kekurangan dari metode scramble diantaranya :

a. Dengan materi yang telah disiapkan, membuat siswa kurang berfikir kritis.

${ }^{9}$ Hanafi, M, Pembelajaran Sejarah Kebudayaan Islam, (Jakarta Pusat: Direktorat Jendral Pendidikan Islam Departemen Agama Islam RI, 2009), h.207 b. Besar kemungkinan siswa mencontek jawaban teman sejawatnya.

c. Meniadakan sikap kreatif siswa.

d. Siswa tinggal menerima bahan mentah. ${ }^{10}$

Tujuan metode Scramble dalam proses pembelajaran adalah sebagai berikut :

a. Membina penguasaan vocabulary untuk bidang bahasa inggris. ${ }^{11}$ Sedangkan dalam pembelajaran Pendidikan Agama Islam bertujuan untuk mempermudahkan para siswa untuk menghafal kata-kata yang sulit atau catatan yang penting. Seperti mengingat nama tokoh-tokoh atau tempat-tempat bersejarah.

b. Scramble merupakan salah satu dari permainan bahasa. Yang bertujuan untuk membangkitkan kembali kesegaran belajar siswa yang mulai melesu. Dan sikap kompetitif yang ada dalam permainan, dapat menorong siswa berlomba-lomba maju yang tidak kalah menarik dari permainan ini adalah materi yang komunikasikan lewat permainan bahasa biasanya berkesan sehingga sukar dilupakan.

c. Permainan scramble bertujuan untuk mengembangkan daya fikir tinggi peserta didik dengan materi (kata acak) yang ada. Sehingga fakta-fakta sejarah yang terdapat dalam pelajaran Pendidikan Agama Islam lebih terasa

\footnotetext{
${ }^{10}$ Imas Kurniasih, Ragam Pengembangan Model Pembelajaran untuk Peningkatan Profesionalitas Guru, (Jakarta: Kata Pena, 2015), cet.2, h. 100

${ }^{11}$ Soeparno, Media Pengajaran Bahasa (Yogyakarta: PT. Intan Pariwara, 1988), h.75
} 
segar dan dekat dengan peserta didik. $^{12}$

\section{Pengertian Hasil Belajar}

Hasil belajar dapat diartikan sebagai tingkat keberhasilan siswa dalam mempelajari materi pelajaran di sekolah yang dinyatakan dalam skor yang diperoleh dari hasil tes mengenal sejumlah materi pelajaran tertentu.

Menurut Nana Sudjana yang dikutip oleh Fatih Arifah dalam bukunya Evaluasi Pembelajaran, Hasil belajar adalah kemampuan-kemampuan yang dimiliki siswa setelah ia menerima pengalaman belajarnya. ${ }^{13}$

Secara sederhana, yang dimaksud dengan hasil belajar siswa adalah kemampuan yang diperoleh anak setelah melalui kegiatan belajar. Karena belajar itu sendiri merupakan suatu bentuk perubahan perilaku yang relatif tetap. Dalam kegiatan pembelajaran atau kegiatan instruksional, biasanya guru menetap kan tujuan belajar. Akan yang berhasil dalam belajar adalah yang berhasil mencapai tujuan-tujuan pembelajaran atau tujuan instruksional. ${ }^{14}$

Ada beberapa macam pembagian hasil belajar, yaitu :

a. Keterampilan dan kebiasaan

b. Pengetahuan dan pengertian

c. Sikap dan cita-cita

Masing-masing jenis hasil belajar tersebut dapat diisi dengan bahan yang telah ditetapkan dalam kurikulum. Meski

${ }^{12}$ Ibid,. h. 207

${ }^{13}$ Fatih Arifah dan Yustisianisa, Evaluasi Pembelajaran, (Yogyakarta : Mentari Pustaka, 2012), h. 65

${ }^{14}$ Ahmad Susanto, Teori Belajar dan Pembelajaran di Sekolah Dasar, (Jakarta: Kencana Prenadamedia Group, 2013), Cet ke-1, h.5 demikian, dalam sistem pendidikan Indonesia, rumusan hasil belajar siswa berkiblat pada klasifikasi yang terbagi dari tiga ranah, yaitu:

a. Ranah Kognitif, adalah hal-hal yang terkait dengan intelektual seseorang, misalnya adalah menghafal, memberikan definisi, mengerjalan soal, mengarang, dan sebagainya. Secara umum, proses kognitif terbagi dalam enam kategori, yaitu pengetahuan (knowledge), pemaham an (understand), apliasi (apply), analisis (analyze), sintesis (syntesis), dan evaluasi (evaluate).

b. Ranah Afektif adalah hal-hal yang terkait dengan sikap seseorang.

c. Ranah Psikomotor adalah ranah yang terkait dengan gerakan. Menurut Nana Sudjana yang dikutip oleh Fatih Arifah dalam bukunya Evaluasi Pembelajaran, bahwa hasil belajar psikomotoris tampak dalam bentuk keterampilan (skills) dan kemampuan bertindak individu. ${ }^{15}$

\section{Faktor yang mempengaruhi hasil belajar}

Menurut teori Gestalt, belajar merupakan suatu proses perkembang an. Artinya bahwa secara kodrati jiwa raga anak mengalami perkembangan. Perkembangan sendiri memerlukan sesuatu baik yang berasal dari diri siswa sendiri maupun pengaruh dari lingkungannya. Berdasarkan teori ini hasil belajar siswa dipengaruhi dua hal, siswa itu sendiri dan lingkungannya. Pertama, Siswa; dalam arti kemampuan berpikir atau tingkah laku intelektual, motivasi, minatm dan kesiapan siswa

\footnotetext{
${ }^{15}$ op.cit, Fatih Arifah, h.66-76
} 
baik jasmani maupun rohani. Kedua, lingkungan; yaotu sarana dan prasarana, kompetensi guru, kreativitas guru, sumber-sumber belajar, metode serta dukungan lingkungan, dan keluarga. ${ }^{16}$

Pendapat yang senada di kemukakan oleh Muhibbin Syah, belajar adalah "tahapan perubahan seluruh tingkah laku individu yang relatif menetap sebagai hasil pengalaman dan interaksi dengan lingkungan yang melibatkan proses kognitif'. ${ }^{17}$ Muhibbin Syah membagi faktor-faktor yang mempengaruhi belajar siswa menjadi tiga macam, yakni :

a. Faktor internal (faktor dari dalam siswa), yakni keadaan / kondisi jasmani dan rohani siswa.

b. Faktor eksternal (faktor dari luar siswa), yakni kondisi lingkungan disekitar siswa.

c. Faktor pendekatan belajar (approach to learning), yakni jenis upaya belajar siswa yang meliputi strategi dan metode yang digunakan siswa untuk melakukan kegiatan pembelajaran materi-materi pelajaran. ${ }^{18}$

Penyelenggaraan evaluasi hasil belajar dalam satu semester terbagi menjadi dua hal, yaitu ; evaluasi formatif dan evaluasi sumatif. Kedua jenis evaluasi ini dilakukan dengan tujuan untuk mengatahui keberhasilan guru dalam mengajar dilihat dari hasil atau prestasi yang dikuasai siswa.

${ }^{16}$ Ahmad Susanto, Teori Belajar dan Pembelajaran di Sekolah Dasar, (Jakarta: Kencana Prenadamedia Group, 2013), Cet ke-1, h. 12

${ }^{17}$ Muhibbin Syah, Psikologi Belajar, (Jakarta: Rajawali Pers, 2012), cet. 12, h.68

${ }^{18}$ Oemar Hamalik, Kurikulum dan Pembelajaran, (Jakarta: Bumi Aksara, 2003), h. 145-146 a. Evaluasi Formatif adalah evaluasi atau penilaian yang dilakukan setelah satu pokok bahasan selesai dipalajari oleh siswa. Evaluasi formatif terutama dimaksud untuk memberi kan umpan balik kepada guru mengenai keberhasilan proses belajar mengajarnya. Dalam hal ini keberhasilan siswa merupakan petunjuk utama yang bersangkutan dan dikenal dengan ulangan harian.

b. Evaluasi sumatif dikenal dengan test yang diselenggarakan oleh guru setelah menempuh satu jangka waktu tertentu. ${ }^{19}$

Menurut E. Mulyasa penilaian hasil belajar dilakukan oleh pendidik dilakukan secara berkesinambungan untuk memantau hasil belajar ada 4 bentuk penilaian diantaranya: ${ }^{20}$

a. Ulangan harian (UH) dilakukan setiap selesai proses pembelajaran dalam kompetensi dasar tertentu. Ulangan harian ini sendiri terdiri dari seperangkat soal yang harus dijawab pada peserta didik, tugas-tugas terstruktur yang berkaitan dengan konsep dan kompetensi dasar yang sedang dibahas. Ulangan harian minimal dilakukan tiga kali dalam setiap semester. Ulangan harian ini terutama ditujukan untuk memperbaiki program pembelajaran, tetapi tidak menutup kemungkinan digunakan untuk tujuan-tujuan lain, misalnya sebagai bahan pertimbangan

${ }^{19}$ Suharsimi Arikunto, dkk. Manajemen Pendidikan, (Yogyakarta: Aditya Media, 2012), cet.1 ed. revisi, h. 106

${ }^{20}$ E. Mulyasa, Kurikulum Tingkat Satuan Pendidikan (KTSP), (Bandung: PT. Remaja Rosdakarya, 2008), h. 258-260 
dalam memberikan nilai bagi para peserta didik.

b. Ulangan Tengah Semester (UTS). Dilakukan setelah pembelajaran mencapai standar kompetensi tertentu (kurang lebih 50 persen SK pada semester tersebut). Ulangan tengah semester terdiri dari seperangkat soal yang harus dijawab para peserta didik mengenal materi standar dan KD yang telah dibahas dalam setengah semester pertama.

c. Ulangan Akhir Semester. Ulangan akhir semester (UAS) sering disebut ulangan umum, dengan bahasan yang diujikan sebagai berikut:

1) UAS pertama soalnya diambil dari materi standar, SK, dan KD semester pertama

2) UAS kedua soalnya merupakan gabungan materi standar, SK, dan KD semester pertama dan kedua.

3) Ulangan kenaikan kelas. Ulangan kenaikan kelas dilakukan pada akhir semester genap, ulangan kenaikan kelas dilakukan untuk menentukan peserta didik yang berhak pindah atau naik ke kelas yang berada di atasnya. Sedangkan ulangan kenaikan kelas yang dilakukan pada semester genap terakhir merupakan ulangan untuk menentukan kelulusan.

Dari uraian di atas dapat disimpulkan terdapat beberapa jenis penilaian yang dapat digunakan oleh guru menilai hasil belajar siswa.

\section{B. METODOLOGI}

Subjek dalam penelitian ini adalah guru dan siswa sekolah Dasar Negeri 007 Tembilahan Hilir Kecamatan Tembilahan. objek penelitian dalam penelitian ini adalah pengaruh metode scramble (kata acak) terhadap hasil belajar siswapada mata Pelajaran Pendidikan Agama Islam kelas IV, V,VI di Sekolah Dasar Negeri 007 Tembilahan Hilir Kecamatan Tembilahan. populasi dalam penelitian ini adalah seluruh siswa kelas IV,V,VI Sekolah Dasar Negeri 007 Tembilahan yang berjumlah 54orang.

Teknik pengumpulan data sebagai berikut: Observasi, dan dokumentasi. Dalam menganalisa data yang berbentuk pengaruh maka penulis memilih rumus Uji t karena rumus ini digunakan untuk menentukan signifikansi pengaruh antara penggunaan metode sramble terhadap hasil belajar siswa. Uji $\mathrm{t}$ digunakan untuk mengetahui ada atau tidaknya perbedaan (kesamaan) dua kelompok data. ${ }^{6}$ Data yang sudah terkumpul penulis kualifikasikan atau tuangkan kedalam bentuk angka-angka sehingga data tersebut bersifat kuantitatif. Pengalihan data ke dalam bentuk kuantitatif ini ditempuh dengan menggunakan rumus Uji t sebagai berikut:

$$
t=\frac{\overline{\mathrm{X}}-\overline{\mathrm{Y}}}{\sqrt{S_{x-y}^{2}+\left(\frac{1}{n_{x}}+\frac{1}{n_{y}}\right)}} 7
$$

${ }^{6}$ Husaini Usman, dkk. Pengantar Statistika (Jakarta: Bumi Aksara, 2006) ed. Kedua, cet., 1, h. 145

${ }^{7}$ Ibid, h. 144 
Keterangan :

$\overline{\mathrm{X}}=$ Rata-rata variabel $\mathrm{x}$ (penggunaan metode)

$\bar{Y} \quad=$ Rata-rata variabel y (hasil belajar

$n_{x}=$ Jumlah banyak variabel $\mathrm{x}$

$n_{y}=$ Jumlah banyak variabel $\mathrm{y}$

\section{B. PEMBAHASAN}

Dari tabel rekapitulasi dapat diketahui bahwa hasil observasi untuk jawaban "Ya" adalah berjumlah 146 dari keseluruhan aspek yang diamati terhadap 18 kali observasi, sedangkan hasil observasi untuk jawaban "tidak" berjumlah sebanyak 34 kali dengan persentasenya. Perhatian hasil dengan rumus: $\mathrm{P} \quad=\frac{F}{N} \times 100 \%$

Untuk menemukan $\mathrm{F}$, penulis menggunakan pengskoran $\mathrm{YA}=1$ dan TIDAK $=0$.

Adapun cara penghitungannya ialah:

$$
\begin{aligned}
& \mathrm{YA}=\quad 146 \times 1=146 \\
& \mathrm{TIDAK}=34 \times 0 \frac{=0+}{146}
\end{aligned}
$$

Maka F = 146

Sedangkan untuk mencari $\mathrm{N}$ adalah dengan cara:

$\mathrm{N}=$ Item observasi $\mathrm{x}$ skor tinggi $\mathrm{x}$ responden $\mathrm{x}$ jumlah observasi

$\mathrm{N}=10 \times 1 \times 1 \times 18$ $=180$

Mana $\mathrm{N}=180$

$\mathrm{P}=\frac{F}{N} \times 100 \%$

$$
=\frac{146}{180} \times 100 \%
$$$$
=81,11 \%
$$

Maka $\mathrm{P}=81,11 \%$
Dari hasil rekapitulasi di atas, dapat disimpulkan bahwa Guru Mata Pelajaran Pendidikan Agama Islam sudah amat baik dalam menjalankan pembelajaran menggunakan metode scramble di kelas IV,V, dan VI dengan persentase $90 \%$ dikategorikan amat baik karena terletak pada interval $80-90 \%$.

Untuk mendapatkan $\Sigma \bar{X}$ yaitu $: \Sigma X: \mathrm{N}_{\mathrm{X}}=146: 18=8,11$

Untuk mendapatkan $\Sigma \bar{Y}$ yaitu :

$\Sigma \mathrm{Y}: \mathrm{N}_{\mathrm{y}}=4496: 54=83,25$

Selanjutnya, masukkan ke dalam rumus Uji $t$ :

$$
t=\frac{\overline{\mathrm{X}}-\overline{\mathrm{Y}}}{\sqrt{S_{x-y}^{2}\left(\frac{1}{n_{x}}+\frac{1}{n_{y}}\right)}}
$$

Langkah 1 :

$$
S_{x-y}^{2}=\frac{\sum(X-\bar{X})^{2}+\sum(Y-\bar{Y})^{2}}{n_{x}+n_{y}-2}
$$

$S_{x-y}^{2}=\frac{17,776+2884,375}{18+54-2}=\frac{2897,151}{70}=41,387$

Langkah ke-2 :

$t=\frac{8,11-83,259}{\sqrt{41,387\left(\frac{1}{18}+\frac{1}{54}\right)}}=\frac{-75,149}{\sqrt{3,065}}=\frac{-75,149}{1,750}=-$ 42,942

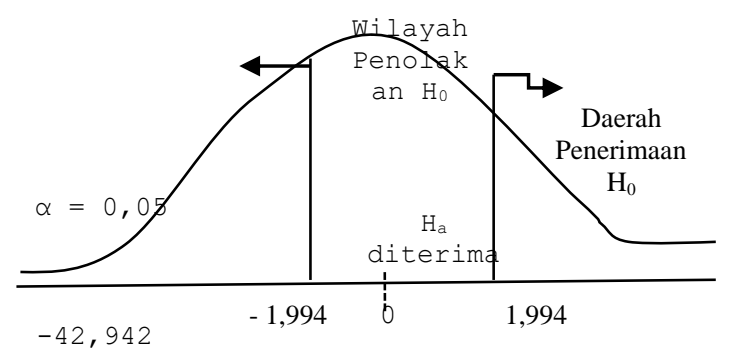

Karena $t_{\text {hitung }}$ terletak pada daerah penolakan, maka $\mathrm{H}_{\mathrm{a}}$ diterima.

Kesimpulan:

Terdapat pengaruh yang signifikan dari hasil belajar siswa setelah diterapkan metode scramble pada mata pelajaran Pendidikan Agama Islam di Sekolah Dasar Negeri 007 Tembilahan Hilir. 


\section{KESIMPULAN}

Berdasarkan hasil penelitian melalui observasi, dokumentasi, dan wawancara, dapat disimpulkan-t tabel $\leq t_{\text {hitung, }}$ maka $\mathrm{H}_{\mathrm{a}}$ diterima,dan $\mathrm{H}_{0}$ ditolak atau -1,994 $\leq$ 60,64. Yaitu terdapat pengaruh penggunaan metode scramble terhadap hasil belajar siswa pada mata pelajaran Pendidikan Agama Islam di Sekolah Dasar Negeri 007 Tembilahan Hilir.

Sedangkan faktor-faktor yang mempengaruhi hasil penelitian sehingga dapat dikategorikan amat baik bagi penggunaan metode scramble diantaranya adalah:

a. Sudah baiknya guru membuat Rencana Pembelajaran.

b. Guru membuat pertanyaan sesuai dengan kompetensi yang ingin dicapai.

c. Sudah baiknya guru dalam menyampaikan tujuan pembelajaran, dan menyampaikan informasi tentang metode yang digunakan.

d. Guru dapat mengorganisir siswa kedalam kelompok, dan mengawasi siswa selama pembelajaran berlangsung.

e. Sudah baiknya guru dalam mengevaluasi hasil belajar siswa dan memberikan tindak lanjut terhadap hasil belajar siswa.

\section{REFERENSI}

Ahmad, Susanto, Teori Belajar dan Pembelajaran di Sekolah Dasar, Jakarta: Kencana Prenadamedia Group, 2013, Cet ke-1

Ahmad, Tafsir, Ilmu Pendidikan Dalam Persfektif Islam, Bandung: PT. Remaja Rosdakarya, 2005
Burhan, Bungin, Metodolgi Penelitian Kuantitatif, Jakarta: Prenada Media Group: 2010

Cholid, Narbuto dan Abu Ahmadi, Metodologi Penelitian, Jakarta: Bumi Aksara, 2002

Desy Anwar, Kamus Lengkap Bahasa Indonesia, Surabaya: Amelia, 2005

E. Mulyasa, Kurikulum Tingkat Satuan Pendidikan (KTSP), Bandung: PT. Remaja Rosdakarya, 2008

Etin, Solihatin, COOPERATIVE LEARNING Analisis Model Pembelajaran IPS, Jakarta: Bumi Aksara, 2008, cet ke-3

Fatih, Arifah dan Yustisianisa, Evaluasi Pembelajaran, Yogyakarta: Mentari Pustaka, 2012

H.M. Musfiqon, Metodologi Penelitian Pendidikan, Jakarta: Prestasi Pustakaraya: 2012

Hamzah, Dkk, Belajar Dengan Pendekatan PAILKEM: Pembelajaran Aktif, Inovatif, Lingkungan, Kreatif, Efektif, Menarik, Jakarta: PT. Bumi Aksara, 2013

Hanafi, M, Pembelajaran Sejarah Kebudayaan Islam, Jakarta Pusat: Direktorat Jendral Pendidikan Islam Departemen Agama Islam RI, 2009

Heri, Jauhari Muchtar, Fikih Pendidikan, Bandung: PT. Remaja Rosdakarya, 2005, Cet. ke-1

Husaini, Usman, dkk. Pengantar Statistika (Jakarta: Bumi Aksara, 2006, ed. Kedua, cet ke-1

Husein, Umar, Metode Penelitian Untuk Skripsi dan Tesis Bisnis, Jakarta: PT Raja Grafindo Persada, 2008

Imas Kurniasih, Ragam Pengembangan Model Pembelajaran untuk Peningkatan Profesionalitas Guru, Jakarta: Kata Pena, 2015, cet ke-2

Istarani, 58 Model Pembelajaran Inovatif, Medan: Perpustakaan Nasional Republik Indonesia, 2004, cet ke-3 
M. Hanafi, Pembelajaran SKI di MI, Jakarta: Kementerian Agama RI, 2010

Moh. Rafa'i, 300 hadits Bekal Da'wah dan Pembinaan Probadi Muslim, Semarang: Wicaksana, 1980

Muhibbin Syah, Psikologi Belajar, Jakarta: Rajawali Pers, 2012, cet ke12

Oemar Hamalik, Kurikulum dan Pembelajaran, Jakarta: Bumi Aksara, 2003

Punaji Setyosari, Metode Penelitian Pendidikan dan Pengembangan, Jakarta: Prenadamedia Group, 2013

Ridwan Abdullah Sani, Inovasi Pembelajaran, Jakarta: Bumi Aksara, 2013

Sanapiah Faisal, Format-Format Penelitian, Jakarta: RajaGrafindo Persada, 2007

Soeparno, Media Pengajaran Bahasa, Yogyakarta: PT. Intan Pariwara, 1988

Sofan, Amri, Proses Pembelajaran Kreatif dan Inovatif dalam Kelas, Jakarta: Pesta Sipustaka Karya, 2010

Suharsimi Arikunto dan Muchtarom, Sejarah Pendidikan Islam, Jakarta: Bumi Aksara, 2009

Suharsimi Arikunto, dkk. Manajemen Pendidikan, Yogyakarta: Aditya Media, 2012, cet.1 ed. revisi

Sukadi, Metodologi penellitian Pendidikan, Jakarta: Bumi Aksara, 2005

Zainal, Arsil, Micro Teaching, Jakarta:

PT. Raja Grafindo, 2012, Cet ke-4 